\title{
Preliminary Seismic Hazard Assessment in West Africa Based on Incomplete Seismic Catalogs
}

\author{
Eddy Ferdinand Mbossi1,2*, Delair Dieudonné Etoundi Ndibi1,2, Pauline Wokwenmendam Nguet1, \\ Jean Marcel Abate Essi³ ${ }^{3}$ Edouard Olivier Biboum Ntomb',2, Jacques Dili-Rake1, Bekoa Ateba1, \\ Tabod Charles Tabod ${ }^{2}$
}

\footnotetext{
${ }^{1}$ Mount Cameroon Observatory, Institute for Geological and Mining Research, Buea, Cameroon

${ }^{2}$ Department of Physics, Faculty of Science, University of Yaoundé 1, Yaoundé, Cameroon

${ }^{3}$ Ore Processing Laboratory, Institute for Geological and Mining Research, Yaoundé, Cameroon

Email: *e.mbossi@yahoo.fr
}

How to cite this paper: Mbossi, E.F., Ndibi, D.D.E., Nguet, P.W., Essi, J.M.A., Ntomb, E.O.B., Dili-Rake, J., Ateba, B. and Tabod, T.C. (2021) Preliminary Seismic Hazard Assessment in West Africa Based on Incomplete Seismic Catalogs. Open Journal of Earthquake Research, 10, 75-93. https://doi.org/10.4236/ojer.2021.102006

Received: March 29, 2021

Accepted: May 28, 2021

Published: May 31, 2021

Copyright $\odot 2021$ by author(s) and Scientific Research Publishing Inc. This work is licensed under the Creative Commons Attribution International License (CC BY 4.0).

http://creativecommons.org/licenses/by/4.0/

\begin{abstract}
West Africa is considered a region of low seismicity. However, the monitoring of earthquake activity by local seismic arrays began very early (as early as 1914) in West Africa but seismic catalogs are very incomplete. In 1991, Bertil studied the seismicity of West Africa based on networks of seismic stations in Ivory Coast and neighboring countries. The reference work of Ambraseys and Adams as well as the recent earthquakes given by the international data centres on the seismicity of West Africa were also used for the computations of earthquake hazard parameters. Different earthquake event data have been compiled and homogenised to moment magnitude $\left(M_{w}\right)$. The obtained catalog covers a period of over four centuries (1615-2021) and contains large historical events and recent complete observations. The complete catalog part has been subdivided into four complete subcatalogs with each a level of completeness. The minimum magnitude and the maximum observed magnitude are equal to 2.89 and 6.8 respectively for the whole catalog. The seismic code software developed by Kijko was used to calculate the earthquake hazard parameters. The results give a $b$ value of $0.83 \pm 0.08$ for the whole period and preliminary seismic hazards curves are also plotted for return periods 25,50 and 100 years. This is a good and practical example showing that this procedure can be used for seismic hazard assessment in West Africa.
\end{abstract}

\section{Keywords}

Africa, Seismic Catalog, Seismic Hazards 


\section{Introduction}

West Africa spans the area between latitude $0^{\circ} \mathrm{N}$ to $15^{\circ} \mathrm{N}$ and longitude $20^{\circ} \mathrm{W}$ to $10^{\circ} \mathrm{E}$. It corresponds to a vast complex that includes the West African Craton, the Pan-African mobile belt and the Mauritanides fold belt (Figure 1).

The edification of West Africa has developed grabens, horsts, and tectonic lineaments which are superimposed on older structures. The tectonics of the Western Africa plate have revealed several continental or oceanic fracture zones. These fracture zones are often interpreted as Atlantic passive margins, the site of seismic strain rates and active deformation [1] [2] [3]. The most seismically active regions are located along the transform faults [4] [5]. The Atlantic Ocean has extended along these faults, especially in its southern part where there is junction of the oceanic fracture zones with the West African continental margin in the Gulf of Guinea (GOG) and continental faults [6]. The GOG region consists of several tectonic structures which are linked to the pan-African Proterozoic orogeny [7] [8]. The seismic activity inland would be related to the reactivation of Paleozoic and Proterozoic tectonic structures of West Africa in the Quaternary [9] [10] [11]. Kutu et al. [12] show the continental active tectonics seems to be linked with the oceanic transform faults in the Gulf of Guinea. Thus, several continental faults may generate large earthquakes $\left(M_{W} \geq 6.0\right)$ and can be associated with the Romanche, Chain and Saint Paul transform faults [4].

Bertil [13] studied the intraplate seismicity for the period 1967 to 1991 . He used data from Lamto seismic networks in Ivory Coast and neighboring countries. According to his results, earthquakes occur at lithospheric preexisting zones

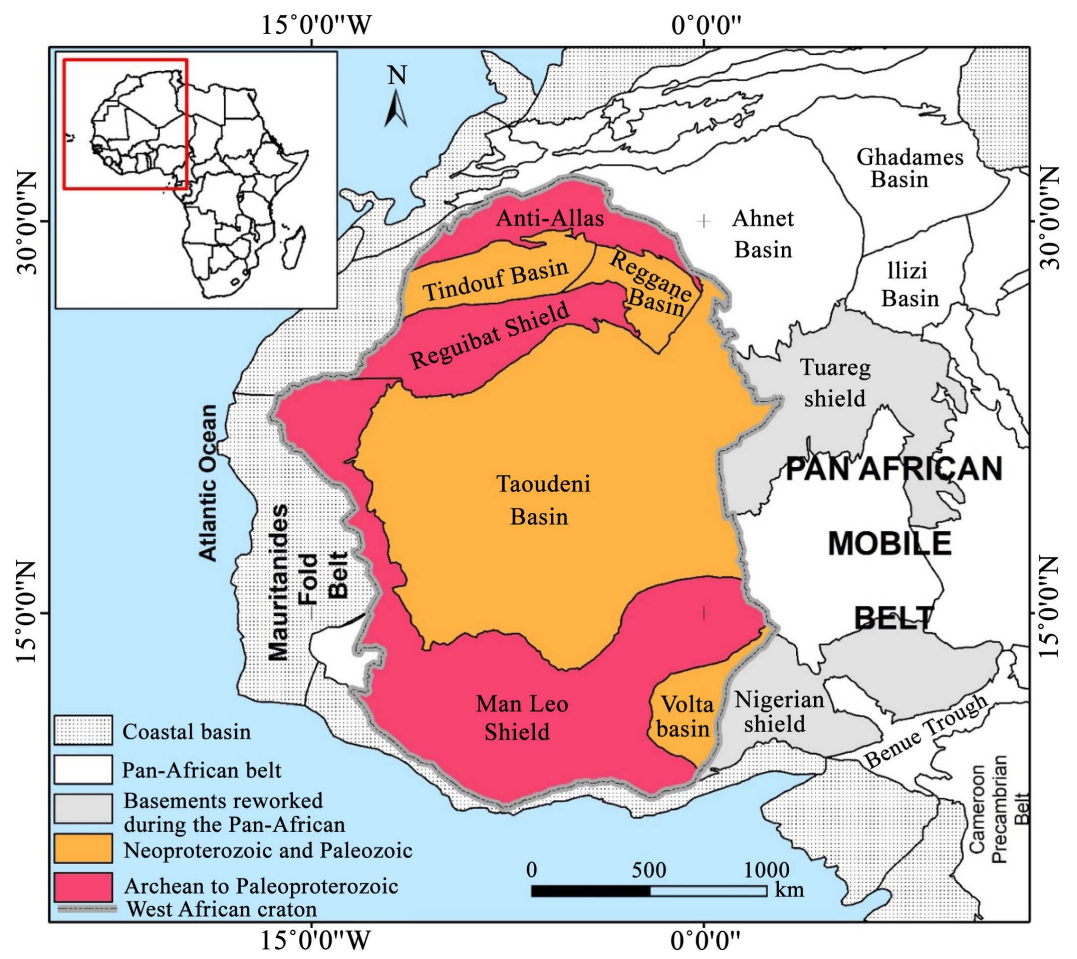

Figure 1. Geological map of West Africa. 
of weakness: continental faults systems and oceanic fracture zones. Although several major historical and recent earthquakes were recorded in the region, the seismicity of West Africa is infrequent according to the geological context. Using the geological and geophysical features, Meghraoui et al. [14] defined from the tectonic regime and seismicity background as well as the geographical situation that West Africa is a stable seismotectonic province. This intraplate area is generally considered as aseismic or having low seismicity. However, the largest magnitude recorded is 6.8 in Ghana. Several other major earthquakes of magnitude 4 to 6 are felt in West Africa and must be taken into consideration for seismic hazard analysis.

The purpose of this work is to assess the seismic hazard level in this province from an incomplete seismic catalog compiled from the available data gathered from previous works and international data centres during the period 1615 to 2021. The seismic parameters are estimated using the computer code describing the probabilistic approaches of Kijko and Sellevoll [15] [16] and Kijko et al. [17].

\section{Geological Setting}

The geological history of West Africa begins with the Archaean era (about 2.5 billion years old). Its different deformation processes correspond to main geodynamic events that affected this region during successive orogenic cycles. West Africa is characterized by formation of craton and its borders, western (Atlantic passive margin) and eastern (area of the active intracontinental rift system of Central and West Africa).

The West African craton has remained stable since the Liberian orogeny. It was partly reworked during Eburnean and Pan-African cycles [18] [19] [20].

The western and northern edges of the craton contain any evidence of significant deformations undergone during the Variscan orogeny [21]. The Pan-African suture in the East was reactivated [22] [23]. At the east end of the craton, the Apto-Albian corresponds to an important geodynamic event marked by the opening of the Equatorial Atlantic Ocean [24] which was characterized by an initiation of oblique rifting in the GOG [25]. This opening accompanied by the "abortion" of the Benue Trough [26], had repercussions in terms of deformation in the north-eastern part of the craton [27] [28] [29]. This episode of deformation is known as the "Austrian phase", and is underlined by tectonic structures that follow North/South directions along the Pan-African suture northwest of the Tuareg Shield [22]. The Cenomano-Turonian bears witness to the most important transgression of the Phanerozoic [30]. West Africa was then partially covered by the sea which was moving southwards [31] [32] [33]. The series associated with this transgression are preserved in the eastern part of the craton [34] [35]. Its extension towards the west on the craton is still unknown.

The Archean and Paleoproterozoic domains of craton are located in two broad shields (the Reguibat Shield to North and the Man-Leo Shield to the south). They are separated by the vast intracratonic Precambrian basin of Taoudeni with its 
sedimentary cover, as well as mobile belts of late Precambrian age, locally affected by a Paleozoic imprint. At the extreme north of the craton is the Anti-Atlas (thrust and fold belt), which represents the northern end of the West African Craton. Just below the Anti-Atlas, is the Tindouf basin whose sedimentary filling is predominantly Paleozoic, with a basal cover of upper Proterozoic age. The western end of the Reguibat Shield consists of the Mauritanides, which are a portion of the Variscan chain in north-west Africa [21] [36]. This complex shows tectonic sheets with E-SE vergence, which extends the fold belt of the Zemmour and then of the Anti-Atlas moving northwards, and whose age of emplacement is estimated between 270 and $330 \mathrm{Ma}$ [21] [36] [37].

West Africa is a seismotectonic area yet poorly known in terms of the current faulting activity, crustal deformation, and their geodynamic causes. However, this region is also seismically active (Figure 2). The geological context is propitious to the presence of active faults that can generate destructive earthquakes [4] [5] [11]. A hazard assessment is therefore required in the area.

\section{Data Analysis and Methodology}

The historical and instrumental regional seismicity data used in our study was obtained from the seismic catalogs prepared during the studies of intraplate seismicity in West Africa from 1615-1991 [4] [13] and the international data

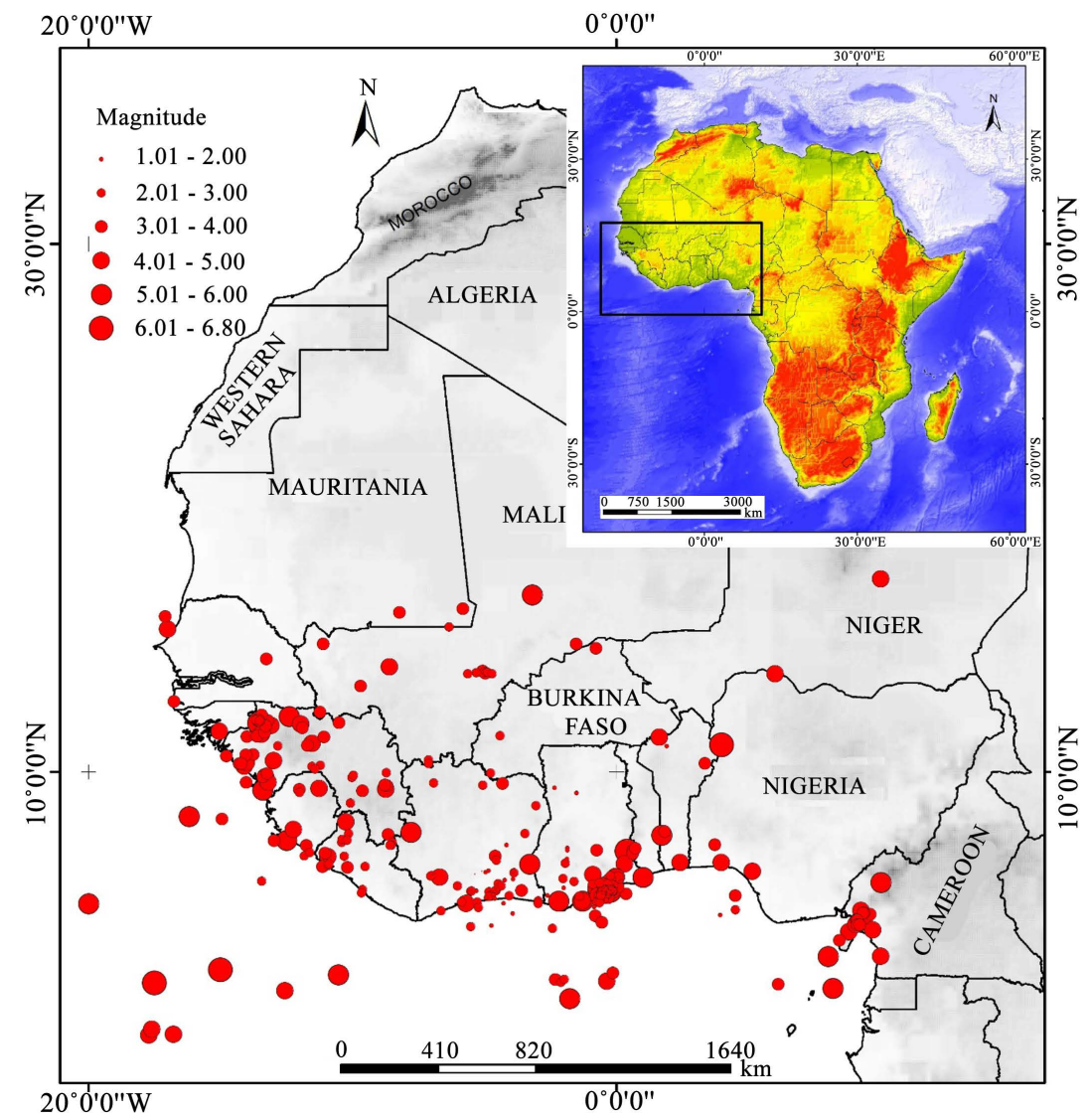

Figure 2. Epicenter map of West Africa. 
centres such as IRIS, USGS, BGS and ISC. Ambraseys and Adams [4] listed several historical and instrumental events between 1615 and 1970 without taking into account those that were doubtful. Bertil seismic catalog (1967-1991) was built entirely from the recordings of networks of seismic stations in Ivory Coast and neighboring countries [13]. These two seismic catalogs were supplemented by those of the international data centres (ISC, USGS, BGS and IRIS) to cover a period from 1615 to 2021 . The resulting catalog has been homogenized to moment magnitude $\left(M_{w}\right)$. According to the approximations carried out by Musson [38], we also adopted that macroseismic magnitude values quoted by Ambraseys and Adams [4] can be taken as roughly equivalent to $M_{w}$ Local magnitude values of Bertil catalog $\left(M_{L}\right)$ were converted to moment magnitude through the relation derived by Grünthal et al. [39]:

$$
M_{w}=0.0376 M_{L}^{2}+0.646 M_{L}+0.53 .
$$

Finally, this seismicity catalog was divided into incomplete historical data and complete observations (Figure 3). The incomplete historical part of catalog covers a period from 1615 to 1795 while the complete part can be subdivided into smaller complete subcatalogs each one with a different time period.

Thus, the earthquake hazard parameters of West Africa are estimated from an algorithm developed by Kijko and implemented in Matlab. The applied procedure provides a maximum likelihood estimate of earthquake hazard parameters, together with their uncertainties, by combining historical and instrumental data. In the description of this analytical method, the moment magnitude $\left(M_{w}\right)$ is reported as $m$; we have chosen to do this because it will be easier to include it in the formulae than to use the conventional notation $M_{w}$

The theoretical background assume that the historical part contains $n_{0}$ largest seismic events, each with a magnitude $m_{0 k}\left(k=1, \cdots, n_{0}\right)$ such as $m_{0 k} \geq m_{0}$ and $m_{0} \geq m_{\min }, m_{\min }$ being overall minimum magnitude of the whole catalog. The time span of the historical part of the catalog $t_{0}$ can be expressed as the sum of the time intervals $t_{0 k}$ between the historical events. The complete part can be divided into $s$ subcatalogs ( $s$ being the number of subcatalogs), each one complete has $n_{i}$ earthquakes, each with a magnitude $m_{i k}(i=1, \cdots, s$;

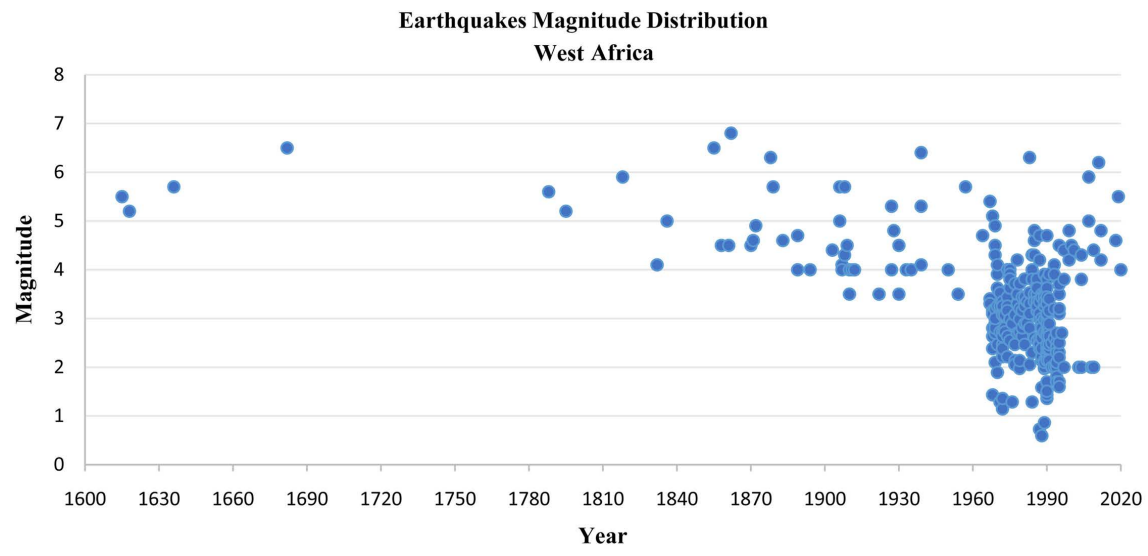

Figure 3. Earthquakes magnitude distribution of seismicity of West Africa. 
$\left.k=1, \cdots, n_{i}\right)$ such as $m_{i k} \geq m_{\min }^{(i)}, \quad m_{\min }^{(i)}$ is threshold magnitude of $i$ th subcata$\log$ with a time span $t_{i}$. The maximum likelihood procedure require that the temporal and magnitude distributions of seismicity for a specified source are respectively described by the Poisson process [40] and the frequency-magnitude Gutenberg-Richter relationship [41].

$$
\log _{10} N=a-b m,
$$

where $a$ and $b$ are parameters, $m$ is the magnitude and $N$ denotes the number of earthquakes of magnitude greater than or equal to the level of completeness magnitude $m_{\min }$. The probability that a total of $n$ earthquakes will be observed during the specified time interval $t$ within a given area by the formula:

$$
P_{n}(\lambda, t)=\frac{(\lambda t)^{n}}{n !} \exp (-\lambda t), \quad n=0,1,2, \cdots
$$

$\lambda \equiv \lambda\left(m_{\min }\right)$ refers to the Poisson distribution parameter and describes the area-characteristic, mean seismic activity rate of earthquakes with magnitudes greater than or equal to $m_{\min }$. The standard seismic hazard analysis procedure requires that earthquake events are independent [42] then the whole catalog must be declustered.

Considering both models (2) and (3), the classic probability density function (PDF) of earthquake magnitude defined by Aki [43]:

$$
f_{M}(m)=\beta \mathrm{e}^{-\beta\left(m-m_{\min }\right)} \text { for } m \geq m_{\min },
$$

while the cumulative distribution function (CDF) of earthquake magnitude is also given by Aki [43]:

$$
F_{M}(m)=1-\mathrm{e}^{-\beta\left(m-m_{\min }\right)} \text { for } m \geq m_{\min },
$$

where the magnitude $m$ is a continuous variable which may take any value greater or equal to than the completeness level $m_{\min }$ and $\beta=b \ln (10)$. The most seismic-hazard assessment procedures do not integrate the temporal variations of seismicity [40] [44] [45] because it has been found that seismicity is temporally stationary [46]. However, large temporal changes of small to moderate magnitude seismicity are often observed in stable intraplate regions [47] [48]. The variations in $b$ values do occur regionally, these variations are often correlated with the regional features of seismic activity and may be significant [17]. In probabilistic seismic hazard analysis (PSHA) studies, the $b$ value is crucial for the accuracy of the final evaluation results. The probabilistic model described by Kijko et al. [17] use Bayesian formalism to account the uncertainty in the parameters $\lambda$ and $b$ by considering them as random variables [49] as well as the uncertainty associated with the earthquake-occurrence models. The seismicity parameters are distributed according to the gamma distribution. Thus, the probability density function (PDF) of gamma distribution is defined as follows [50]:

$$
f_{\mathrm{X}}(x)=x^{(q-1)} \frac{p^{q}}{\Gamma(q)} \exp (-p x) \text { with } x, p, q>0 .
$$


In Equation (6), $\Gamma(q)$ denotes gamma function [50]:

$$
\Gamma(q)=\int_{0}^{\infty} y^{q-1} \exp (-y) \mathrm{d} y, \quad q>0
$$

where $p$ and $q$ are related to the mean $\mu_{x}\left(\mu_{x}=\frac{q}{p}\right)$ and the variance $\sigma_{x}^{2}$ $\left(\sigma_{x}^{2}=\frac{q}{p^{2}}\right)$ of the distribution.

The coefficient of variation expresses the uncertainty related to the variation of a given parameter relative to its mean is given by:

$$
v_{x}=\frac{\sigma_{x}}{\mu_{x}}
$$

The Bayesian CDF of earthquake magnitudes derived from Equations (5) and (6) will take the form of the Bayesian Exponential-Gamma distribution, as described by [51]:

$$
F_{M}\left(m \mid v_{\beta}, m_{\min }\right)=C_{\beta}\left[1-\left(\frac{p_{\beta}}{p_{\beta}+m-m_{\min }}\right)^{q_{\beta}}\right] .
$$

In which $p=\bar{\beta} /\left(\sigma_{\beta}\right)^{2}, q=\left(\bar{\beta} / \sigma_{\beta}\right)^{2}$ with $\bar{\beta}$ and $\sigma_{\beta}$ being respectively the mean value and the standard deviation of the parameter $\beta . C_{\beta}$ being a normalizing coefficient of the form:

$$
C_{\beta}=\left[1-\left(\frac{p_{\beta}}{p_{\beta}+m_{\max }-m_{\min }}\right)^{q_{\beta}}\right]^{-1}
$$

The poisson distribution (3) combined with the gamma distribution (6) will become the Poisson-gamma Bayesian distribution:

$$
P_{n}\left(\bar{\lambda}, t, v_{\lambda}\right)=\frac{\Gamma\left(n+q_{\lambda}\right)}{n ! \Gamma\left(q_{\lambda}\right)}\left(\frac{p_{\lambda}}{t+p_{\lambda}}\right)^{q_{\lambda}}\left(\frac{t}{t+p_{\lambda}}\right)^{n},
$$

where $p_{\lambda}=\bar{\lambda} / \sigma_{\lambda}^{2}$ and $q_{\lambda}=\left(\bar{\lambda} / \sigma_{\lambda}\right)^{2}$ are the parameters of gamma distribution (6), $\bar{\lambda}$ the mean value of the activity rate $\lambda$.

As $q_{\lambda}=\bar{\lambda} p_{\lambda}$ and $q_{\beta}=\bar{\beta} p_{\beta}$ Equations (8) and (10) may respectively be rewritten in the form [17]:

$$
\begin{gathered}
F_{M}\left(m \mid v_{\beta}, m_{\min }\right)=C_{\beta}\left[1-\left(\frac{q_{\beta}}{q_{\beta}+\bar{\beta}\left(m-m_{\min }\right)}\right)^{q_{\beta}}\right] \\
P_{n}\left(\bar{\lambda}, t, v_{\lambda}\right)=\frac{\Gamma\left(n+q_{\lambda}\right)}{n ! \Gamma\left(q_{\lambda}\right)}\left(\frac{q_{\lambda}}{\bar{\lambda} t+q_{\lambda}}\right)^{q_{\lambda}}\left(\frac{\bar{\lambda} t}{\bar{\lambda} t+q_{\lambda}}\right)
\end{gathered}
$$

In this case, the normalizing coefficient takes the form:

$$
C_{\beta}=\left[1-\left(\frac{q_{\beta}}{q_{\beta}+\bar{\beta}\left(m_{\max }-m_{\min }\right)}\right)^{q_{\beta}}\right]^{-1},
$$

and $(\bar{\lambda}, \bar{\beta})$ are calculated by applying the maximum likelihood procedure. 
Using Equations (11) and (13), the Bayesian PDF of earthquake magnitudes are defined as [17]:

$$
f_{M}\left(m \mid v_{\beta}, m_{\min }\right)=C_{\beta} \bar{\beta}\left(\frac{q_{\beta}}{q_{\beta}+\bar{\beta}\left(m-m_{\min }\right)}\right)^{q_{\beta}+1}
$$

The maximum likelihood estimators of the parameters $\bar{\lambda}$ and $\bar{\beta}$ respectively denoted $\hat{\bar{\lambda}}$ and $\hat{\bar{\beta}}$ are the values of $\bar{\lambda}$ and $\bar{\beta}$ that maximizes the likelihood function $L(\Theta)$ for a given maximum area-characteristic earthquake magnitude $m_{\max }$. Thus, maximization of the likelihood function is obtained by solving the system of two equations $\frac{\partial l}{\partial \bar{\lambda}}=0$ and $\frac{\partial l}{\partial \bar{\beta}}=0$, in which $l=\ln [L(\Theta)]$. The uncertainties of the parameters $\bar{\lambda}$ and $\bar{\beta}$ expressed as a formal estimate of the variance of $(\hat{\bar{\lambda}}, \hat{\bar{\beta}})$ are given from the equations describing the approximate variance-covariance matrix of vector $(\hat{\bar{\lambda}}, \hat{\bar{\beta}})$ such as [52]:

$$
D(\hat{\bar{\lambda}}, \hat{\bar{\beta}})=-\left[\begin{array}{ll}
\frac{\partial^{2} l}{\partial \bar{\lambda}^{2}} & \frac{\partial^{2} l}{\partial \bar{\lambda} \partial \bar{\beta}} \\
\frac{\partial^{2} l}{\partial \bar{\beta} \partial \bar{\lambda}} & \frac{\partial^{2} l}{\partial \bar{\beta}^{2}}
\end{array}\right]^{-1},
$$

in which derivatives are calculated at the point $\bar{\lambda}=\hat{\bar{\lambda}}$ and $\bar{\beta}=\hat{\bar{\beta}}$. Equation (15) provides a good approximation of the event variance-covariance matrix for sufficiently large $n$. It should be noted that the formulation (15) does not provide estimation of the standard error of the estimator of $m_{\max }$ denoted $\hat{m}_{\max }$.

The likelihood function $L(\Theta)$ calculated from all available data is the product likelihood functions, based on the historical and complete parts of the cata$\log$, as

$$
L(\Theta)=L_{H}(\Theta) \times L_{C}(\Theta)
$$

In Equation (16), the likelihood function $L_{H}(\Theta)$ of the parameters $\bar{\lambda}$ and $\bar{\beta}$ for the historical events is [17]:

$$
L_{H}(\Theta) \equiv L_{H}\left(\Theta \mid m_{0}, t_{0}, v\right)=\prod_{k=1}^{n_{0}} f_{M}^{\max }\left(m_{0 k} \mid v_{\beta}, m_{0}, t_{0 k}\right),
$$

in which $f_{M}^{\max }\left(m_{0 k} \mid v_{\beta}, m_{0}, t_{0 k}\right)$ which denotes the PDF of the largest earthquake magnitude within the time period $t_{0 k}$ takes the form [17]:

$$
f_{M}^{\max }\left(m_{0 k} \mid v_{\beta}, m_{0}, t_{0 k}\right)=\frac{\bar{\lambda}_{0} t q_{\lambda} f_{M}\left(m_{0 k} \mid v_{\beta}, m_{0}\right) F_{M}^{\max }\left(m_{0 k} \mid v_{\beta}, m_{0}, t_{0 k}\right)}{q_{\lambda}+\bar{\lambda}_{0} t\left[1-F_{M}\left(m_{0 k} \mid v_{\beta}, m_{0}\right)\right]},
$$

with $\bar{\lambda}_{0}=\bar{\lambda}\left[1-F_{M}\left(m_{0 k} \mid v_{\beta}, m_{0}\right)\right]$, the mean activity rate for earthquakes with magnitudes $m_{0 k} \geq m_{0}$ and $\bar{\lambda} \equiv \bar{\lambda}\left(m_{\min }\right)$ as the mean activity rate corresponding to the magnitude value $m_{\min }$. The functions $F_{M}\left(m_{0 k} \mid v_{\beta}, m_{0}\right)$ and $f_{M}\left(m_{0 k} \mid v_{\beta}, m_{0}\right)$ are respectively the CDF and PDF of earthquake magnitudes obtained in Equations (11) and (14). According to Equation (16), the likelihood 
function $L_{C}(\Theta)$ based on all $s$ complete subcatalogs is defined as [17]:

$$
L_{C}(\Theta)=\prod_{i=1}^{s} L_{i}\left(\bar{\lambda} \mid n_{i}, t_{i}\right) L_{i}\left(\bar{\beta} \mid m_{i k}\right) \text {, with }\left(k=1, \cdots, n_{i}\right)
$$

where

$$
L_{i}\left(\bar{\lambda} \mid n_{i}, t_{i}\right)=\left(\bar{\lambda}^{(i)} t_{i}+q_{\lambda}\right)^{-q_{\lambda}}\left(\frac{\bar{\lambda}^{(i)} t_{i}}{\bar{\lambda}^{(i)} t_{i}+q_{\lambda}}\right)^{n_{i}},
$$

and

$$
L_{i}\left(\bar{\beta} \mid m_{i k}\right)=\left[C_{\beta} \bar{\beta}\right]^{n_{i}} \prod_{k=1}^{n_{i}}\left[1+\frac{\bar{\beta}}{q_{\beta}}\left(m_{i k}-m_{\min }^{(i)}\right)\right]^{-\left(q_{\beta}+1\right)},
$$

$L_{i}\left(\bar{\lambda} \mid n_{i}, t_{i}\right)$ and $L_{i}\left(\bar{\beta} \mid m_{i k}\right)$ are the likelihood functions of each complete subcatalog $i(i=1, \cdots, s)$ where $\bar{\lambda}^{(i)}=\bar{\lambda}\left[1-F_{M}\left(m_{\min }^{(i)} \mid v_{\beta}, m_{\min }\right)\right]$ is the mean earthquake activity rate, corresponding to the magnitude level of completeness $m_{\min }^{(i)} . F_{M}\left(m_{\min }^{(i)} \mid v_{\beta}, m_{\min }\right)$ is defined in Equation (11).

The maximum possible magnitude $m_{\max }$ of earthquake occurring within a specified source is calculated using Bayesian formalism [53]:

$$
\hat{m}_{\max }=m_{\max }^{\text {obs }}+\frac{\delta^{1 / q} \exp \left[n r^{q} /\left(1-r^{q}\right)\right]}{\bar{\beta}}\left[\Gamma\left(-1 / q, \delta r^{q}\right)-\Gamma(-1 / q, \delta)\right] .
$$

In Equation (17), $\Gamma(\cdot, \cdot)$ denotes the complementary incomplete gamma function [50], $p$ and $q$ are defined as the Bayesian distribution parameters,

$r=p_{\beta} /\left(p_{\beta}+m_{\max }-m_{\min }\right) \quad c_{1}=\exp \left[-n\left(1-C_{\beta}\right)\right]$ and $\delta=n C_{\beta}$ with $C_{\beta}$ being a normalizing coefficient defined in Equation (9). The variance of the Bayesian estimator $\hat{m}_{\max }$ corresponding to its uncertainty can be approximated as [53]:

$$
\operatorname{Var}\left(\hat{m}_{\max }\right)=\sigma_{M}^{2}+\left[\frac{\delta^{1 / q} \exp \left[n r^{q} /\left(1-r^{q}\right)\right]}{\bar{\beta}}\left[\Gamma\left(-1 / q, \delta r^{q}\right)-\Gamma(-1 / q, \delta)\right]\right]^{2}
$$

The procedure also accepts time gaps (periods during there is no seismic record) and takes into account the uncertainty in the magnitude of seismic events and treats them as random errors following a Gaussian distribution with zero mean and standard deviation $\sigma$ [54]. Thus, the seismicity parameters are calculated simultaneously by an iterative scheme in the seismic code software developed by Kijko.

\section{Results}

The outlined technique was applied to West Africa to estimate the earthquake hazard parameters. Table 1 lists the incomplete data of the largest historical events while the complete part of the catalog was subdivided into four subcatalogs, each with a different level of completeness (Table 2).

For each subcatalog, the level of completeness was determined using the maximum curvature technique [55]. The magnitude of completeness $m_{\min }^{(i)}$ estimate is based on the departure of the Gutenberg-Richter frequency-magnitude 
Table 1. A part of historical catalog of West Africa.

\begin{tabular}{cccc}
\hline Event & Date & Magnitude & Standard error of earthquake magnitude determination \\
\hline 1 & 1615 & 5.5 & 0.3 \\
2 & 18 February 1618 & 5.2 & 0.3 \\
3 & 18 December 1636 & 5.7 & 0.3 \\
4 & 10 July 1682 & 6.5 & 0.3 \\
5 & 1788 & 5.6 & 0.3 \\
6 & 20 May 1795 & 5.2 & 0.3 \\
\hline
\end{tabular}

Table 2. A summary of the complete parts of the West Africa Catalog.

\begin{tabular}{cccccc}
\hline Subcatalog & Start Date & End Date & $\begin{array}{c}\text { Level of } \\
\text { Completeness } \\
m_{\min }^{(i)}\end{array}$ & $\begin{array}{c}\text { Number } \\
\text { of events }\end{array}$ & $\begin{array}{c}\text { Standard error } \\
\text { of earthquake } \\
\text { magnitude } \\
\text { determination }\end{array}$ \\
\hline 1 & January 1818 & 31 December 1967 & 3.9 & 41 & 0.2 \\
2 & 24 January 1968 & 10 October 1982 & 3.07 & 43 & 0.2 \\
3 & 1 January 1983 & 6 March 1997 & 2.89 & 77 & 0.2 \\
4 & 11 January 1999 & 3 February 2021 & 4.25 & 13 & 0.1 \\
\hline
\end{tabular}

distribution (Equation (2)) from its linear trend. Table 2 summarizes the dates, completeness magnitude $m_{\min }^{(i)}$ and the number of events above $m_{\min }^{(i)}$ as well as the standard error of earthquake magnitude determination in each subcatalog. The frequency-magnitude plots for each subcatalog are presented in Figure 4.

It was assumed that earthquake magnitudes for the incomplete part of the catalog were determined with a standard error equal to 0.3 magnitude units and those of the complete part are assumed to have a magnitude standard error of 0.2 or 0.1 (Table 2). The temporal variation and the effects of swarms included in the estimation process of parameters $\bar{\lambda}$ and $\bar{\beta}$, were equal to 0.5 . The possibility of including any additional information for the case of poor quality seismic catalog is required in the estimation of average values of seismic hazard parameters for West Africa. Kijko and Graham [56] suggest therefore that the value of $b_{\text {prior }}$ and its standard deviation $\sigma_{\text {prior }}$ obtained from the maximization of likelihood function (16) are roughly considered to be the same as for another area of similar seismogenic features. Thus, the chosen arbitrary values of $b_{\text {prior }}$ and standard error of $\sigma_{\text {prior }}$ are 1.0 and 0.1 respectively because the $b$ value of a stable continental region is generally close to 1.0 [57] [58] [59]. The value of $b_{\text {prior }}$ parameter will also help to stabilize the results.

The obtained estimates of $b$ value, mean activity rate occurrence $\lambda$, and areacharacteristic maximum possible magnitude $m_{\max }$ for West Africa, together with their standard deviations are given in Table 3.

The seismic hazard curves are also plotted; Figure 5 show the return period of magnitude event $m \leq m_{\max }$, Figure 6 describes the annual probability of exceeding a given magnitude at least once and finally Figure 7, the probabilities of 


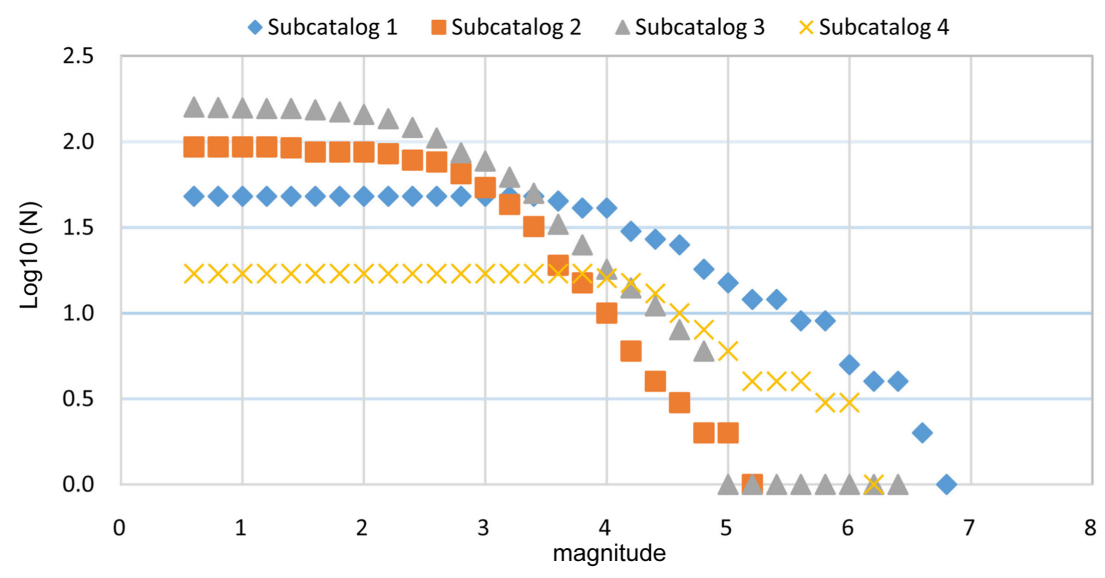

Figure 4. Graphs showing the frequency-magnitude distributions of each seismic subcatalog of West Africa. The magnitude bin is 0.2. The level of completeness represents the magnitude at which the curve deviates from its linear trend.

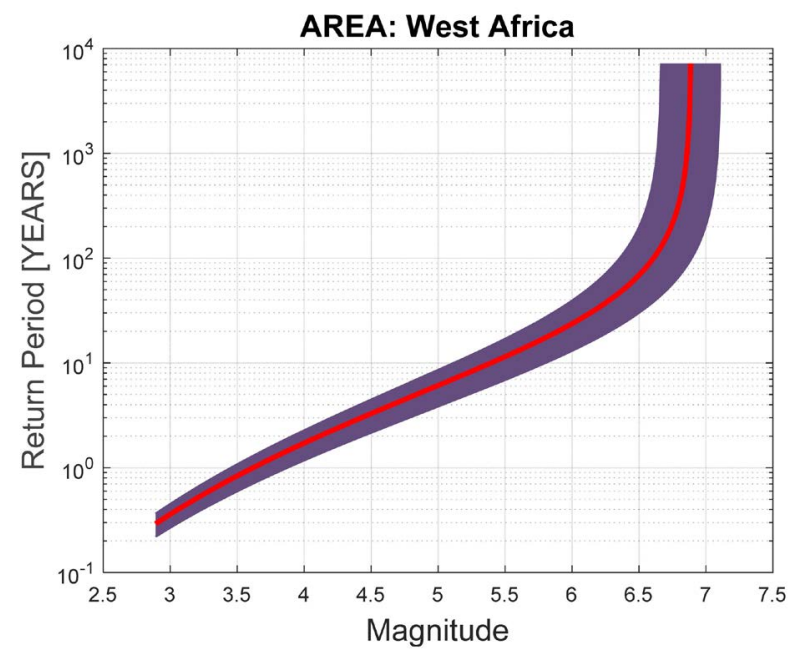

Figure 5. The mean return periods of magnitude events from West Africa.

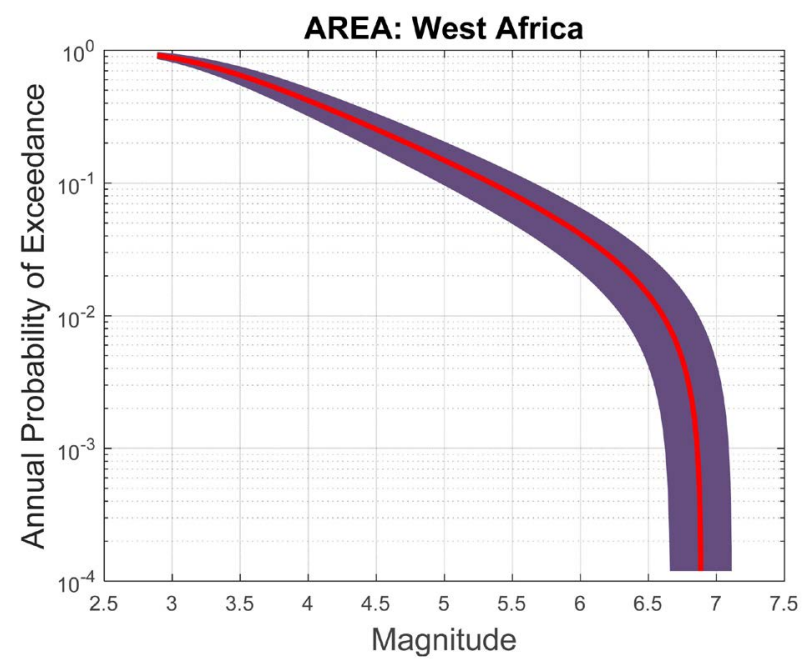

Figure 6. The probability that a given magnitude will be exceeded at least once in any year. 


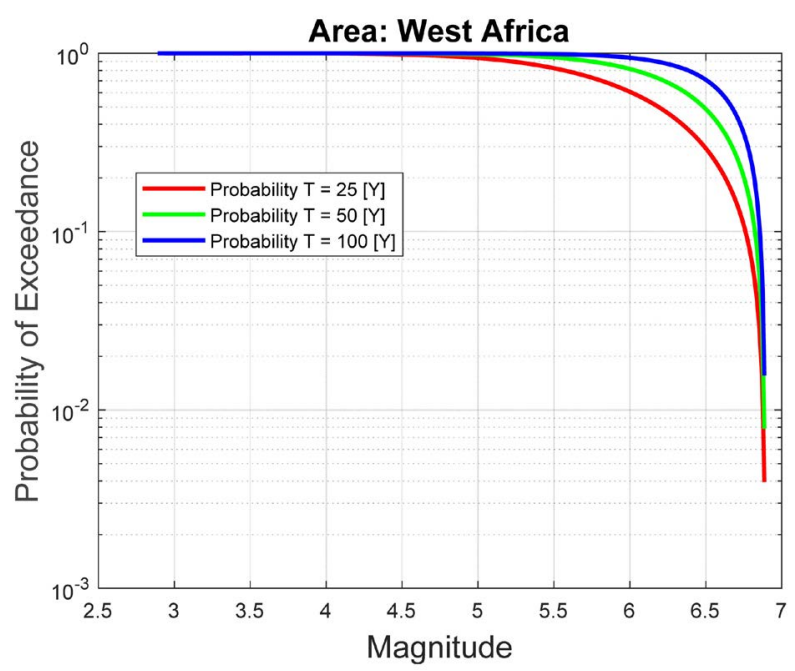

Figure 7. Graphs showing the probability of exceedance of earthquake events from West Africa for the next 25, 50 and 100 years.

Table 3. Earthquake hazard parameters of West Africa.

\begin{tabular}{ccc}
\hline$\beta(b$ value $)$ & $\lambda\left(m_{\min }=2.89\right)$ & $m_{\max }\left(m_{\max }^{o b s}=6.8 \pm 0.2\right)$ \\
\hline $1.92 \pm 0.18(0.83 \pm 0.08)$ & $3.425 \pm 0.850$ & $6.89 \pm 0.22$ \\
\hline
\end{tabular}

exceedance of earthquake events for the next 25, 50 and 100 years. Each graph also provides the calculated level of confidence for the calculated values. The main results show that there is about $50 \%$ of probability that at least one event will exceed the magnitude $M_{w}=6.5$ in the next 50 years and the return period of earthquake event with moment magnitude $M_{w} \geq 6.5$ is at least one century.

\section{Discussions}

Seismic hazard assessment in West Africa is rather difficult. The informations about the historical seismicity are very incomplete. Instrumental monitoring of seismicity in West Africa started from 1914 onwards [60] with the installation of seismic networks for different local studies [13] [61] [62] [63] [64]. Nevertheless, very few data are available and some testimonies were scarce and imprecise. The first formal seismological bulletins of West Africa for a significant period was published by Ambraseys and Adams [4]. They listed the largest earthquakes with a rough moment magnitude estimate $\left(M_{w}\right)$ recorded between 1615 and 1970. It was supplemented by the database built from Lamto seismic network of Ivory Coast. Bertil catalog is assumed to be the most complete of the region during 26 years. However, the location of earthquake events are not well constrained for epicentral distances greater than $600 \mathrm{~km}$ and the most of earthquake events with $M_{w} \leq 2.0$ are near to the Lamto seismic network. The seismic events of $M_{w} \geq 3.0$ have been detected in neighboring countries and GOG [13]. In spite of these constraints and the choice done by Musson [13] to do not include them in the seismicity of West Africa, we considered these earthquake events and extended 
the time period (1615-2021) in order to obtain an accurate seismic hazard assessment of West Africa. We can explain it simply because the work carried out by Bertil [13] remains unpublished. In addition, seismicity monitoring of West Africa is very intermittent over long period and there is no available formal seismological bulletin published recently to improve knowledge of low seismicity in this moment. Thus, the technique of Kijko et al. [17] which use the incomplete historical data mixed with recent complete observations, is adequated to apply to the West Africa dataset.

The seismicity parameters calculated give a $b$ value (Table 3 ) of about 0.83 . This $b$ value approaching unity supports that the seismicity of West Africa is associated with the tectonic areas. According to Agrawal [65], that tectonic earthquakes are characterized by the $b$ value from 0.5 to 1.5 and are more frequently around 1.0 for seismically active regions. The $b$ value depends on structural heterogeneity and stress distributions in space [66] [67]. In a stable intraplate area, the $b$ value tend to be lower than those for plate boundary zones, which are usually around 1 . One possible explanation for this observation is that within the plate, the rocks are not as intensively fractured [46]. Normally, there is a greater abundance of fractures in a plate boundary which could lead to a larger ratio of smaller events to larger events (large $b$ values). Freeth [68] considered boundary plate tectonic forces to be responsible for continental tectonics in West Africa and suggested therefore that extensional stresses in the plate boundary could make some continental faults active. According to Talwani [69], Intraplate Earthquakes (IPEs) occur within the continental zone when the magnitude of local stresses become comparable with the regional stress (boundary plate). In addition, the strain rate is relatively very low in the western side of the African plate [70] [71]. Then, IPEs are associated with larger stress drops therefore large earthquakes should have larger return period. Thus, the hazard curves obtained (Figure 7) show that earthquake event with magnitude greater than 6.5 can probably occur every century in West Africa.

The maximum observed magnitude (6.8) in the West Africa catalog fall into the southern part of Ghana. This magnitude had previously been used to assess magnitude of the largest possible earthquake for Ghana [72]. They used the deterministic method based on empirical formula of Gupta [73]. Normally, the maximum credible magnitude is assumed to occur at the minimum possible distance from the site, without providing any indication of the likelihood of its occurrence during a specified exposure period. In addition, it is very difficult to identify individual active fault zones because of their rarity and the efforts to study them have been limited. In this case, various tectonic and fault rupture parameters such as length, area and dislocation, cannot be available. Thus, regional maximum magnitude can only be based on the seismicity, and geological, geophysical and structural features available in the West Africa. The seismological information focuses on the maximum observed magnitude and statistical analysis of the available seismic catalog while the geological information is used to identify different tectonic features. Here, we are considered West Africa as a 
seismogenic province so we are not need to subdivide into seismic sources. According to Gupta [73], the probabilistic approaches are able to give the results more reliable. Thereby, we are chosen to apply the probabilistic procedure developed by Kijko et al. [17] to calculate the maximum regional magnitude in West Africa because it is used for the areas with both low and high seismicity, including cases where the catalogs are incomplete. This procedure also integrates the effects of all the earthquakes of all possible magnitudes and at all significant distances from the site during a specified exposure time, taking into account the associated uncertainties and the uncertainty of earthquake-occurrence models. In PSHA, $m_{\max }$ plays an important role in assessment of long return periods [74] therefore its value should not be overestimated.

\section{Conclusion}

We are focused our study on the estimation of earthquake hazard parameters of West Africa. The sismotectonic analysis in the region showed the occurrence of strong earthquakes, some of which are associated with offshore faults closer to the coastline [11] [12] [14]. Unfortunately, West Africa is not well covered by seismic stations permanently operating and the earthquake catalogs are very incomplete. In this preliminary study, the probabilistic approach developed by Kijko et al. [17] has been successfully tested. The maximum regional magnitude is around 7 and hazard curves are plotted for return periods of 25, 50 and 100 years. As a result, we observed the return period of the largest earthquake is around one century but we also have $50 \%$ of chance to have an earthquake of magnitude 6 occur at least once in West Africa in the next 25 years. These results we lead to take into account the main seismic source zones of West Africa most affected by large earthquakes in the estimation of the level seismic hazard in this part of Africa.

\section{Acknowledgements}

This work was carried out at the Institute for Geological and Mining Research, Cameroon. The authors sincerely thank Professor A. Kijko for giving us access to its seismic code software and we also thank the Department of Physics of the University of Yaounde I for their prompt collaboration.

\section{Conflicts of Interest}

The authors declare no conflicts of interest regarding the publication of this paper.

\section{References}

[1] Tuzo Wilson, J. (1965) A New Class of Faults and Their Bearing on Continental Drift. Nature, 207, 343-347. https://doi.org/10.1038/207343a0

[2] Brune, J.N. (1968) Seismic Moment, Seismicity and Rate of Slip along Major Fault Zones. Journal of Geophysical Research, 73, 777-784. https://doi.org/10.1029/JB073i002p00777 
[3] Le Pichon, X. and Hayes, D.E. (1971) Marginal Offsets, Fracture Zones, and the Early Opening of the South Atlantic. Journal of Geophysical Research, 76, 6283-6293. https://doi.org/10.1029/JB076i026p06283

[4] Ambraseys, N.N. and Adams, R.D. (1986) Seismicity of West Africa. Annals of Geophysics, 4, 679-702.

[5] Rouland, D., Legrand, D., Cisternas, A., Streng, A., Gir, R. and Souriau, A. (2016) Historical Seismicity in Oceans from Sailors Testimonies. Journal of Seismology, 20, 251-264. https://doi.org/10.1007/s10950-015-9523-y

[6] Francheteau, J. and Le Pichon, X. (1972) Marginal Fracture Zones as Structural Framework of Continental Margins in the South Atlantic Ocean. Journal of Geophysical Research, 56, 991-1007. https://doi.org/10.1306/819A40A8-16C5-11D7-8645000102C1865D

[7] Langer, C.J., Bonilla, M.G. and Bollinger, G.A. (1987) Aftershocks and Surface Faulting Associated with the Intraplate Guinea, West Africa, Earthquake of 22 December, 1983. Bulletin of the Seismological Society of America, 77, 1579-1601.

[8] Antobreh, A.A., Faleide, A.J., Tsikalas, F. and Planke, S. (2009) Rift-Shear Architecture and Tectonic Development of the Ghana Margin Deduced from Multichannel Seismic Reflection and Potential Field Data. Marine and Petroleum Geology, 26, 345-368. https://doi.org/10.1016/j.marpetgeo.2008.04.005

[9] Blundell, D.J. (1976) Active Faults in West Africa. Earth and Planetary Science Letters, 31, 287-290. https://doi.org/10.1016/0012-821X(76)90221-1

[10] Wright, J.B. (1976) Fracture Systems in Nigeria and Initiation of Fracture Zones in the South Atlantic. Tectonophysics, 34, T43-T47. https://doi.org/10.1016/0040-1951(76)90093-7

[11] Amponsah, P., Leydecker, G. and Muff, R. (2012) Earthquake Catalogue of Ghana for the Time Period 1615-2003 with Special Reference to the Tectono-Structural Evolution of South-East Ghana. Journal of African Earth Sciences, 75, 1-13. https://doi.org/10.1016/j.jafrearsci.2012.07.002

[12] Kutu, J.M., Anani, C.Y., Asiedu, D.K., Manu, J., Hayford, E. and Oppong, I. (2013) Recent Seismicity of Southern Ghana and Re-Interpretation of the 1939 Accra Earthquake: Implications for Major Recurrences of Major Earthquakes. International Journal of Basic and Applied Sciences, 2, 322-331. https://doi.org/10.14419/ijbas.v2i4.1120

[13] Bertil, D. (1991) Etude de la sismicité intraplaque en Afrique de l'Ouest (1967-1991) à partir du réseau de stations sismologiques de Lamto-Cote d'Ivoire. Thèse de doctorat en Terre, océan, espace, Université de Paris VI, Laboratoire de Géophysique Appliquée, 137 p.

[14] Meghraoui, M., Amponsah, P., Ayadi, A., Ayele, A., Ateba, B., Bensuleman, A., Delvaux, D., El Gabry, M., Fernandes, R.-M., Midzi, V., Roos, M. and Timoulali, Y. (2016) The Seismotectonic Map of Africa. Episodes, 39, 9-18. https://doi.org/10.18814/epiiugs/2016/v39i1/89232

[15] Kijko, A. and Sellevoll, M.A. (1989) Estimation of Earthquake Hazard Parameters from Incomplete Data Files, Part I, Utilization of Extreme and Complete Catalogues with Different Threshold Magnitudes. Bulletin of the Seismological Society of America, 79, 645-654.

[16] Kijko, A. and Sellevoll, M.A. (1992) Estimation of Earthquake Hazard Parameters from Incomplete Data Files, Part II, Incorporation of Magnitude Heterogeneity. Bulletin of the Seismological Society of America, 82, 120-134.

[17] Kijko, A., Smit, A. and Sellevoll, M. (2016) Estimation of Earthquake Hazard Para- 
meters from incomplete Data Files. Part III. Incorporation of Uncertainty of Earthquake-Occurrence Model. Bulletin of the Seismological Society of America, 106, 1210-1222. https://doi.org/10.1785/0120150252

[18] Liégeois, J.P., Claessens, W., Camara, D. and Klerkx, J. (1991) Short-Lived Eburnean Orogeny in Southern Mali. Geology, Tectonics, U-Pb and Rb-Sr Geochronology. Precambrian Research, 50, 111-136. https://doi.org/10.1016/0301-9268(91)90050-K

[19] Black, R. and Liégeois, J.P. (1993) Cratons, Mobile Belts, Alkaline Rocks and Continental Lithospheric Mantle: The Pan-African Testimony. Journal of the Geological Society, 150, 89-98. https://doi.org/10.1144/gsjgs.150.1.0088

[20] Soumaila, A., Henry, P., Garba, Z. and Rossi, M. (2008) REE Patterns, Nd-Sm and $\mathrm{U}-\mathrm{Pb}$ Ages of the Metamorphic Rocks of the Diagorou-Darbani Greenstone Belt (Liptako, SW Niger): Implication for Birimian (Paleoproterozoic) Crustal Genesis. Journal of the Geological Society, 297, 19-32. https://doi.org/10.1144/SP297.2

[21] Michard, A., Soulaimani, A., Hoepffner, C., Ouanaimi, H., Baidder, L., Rjimati, E.C. and Saddiqi, O. (2010) The South-Western Branch of the Variscan Belt: Evidence from Morocco. Tectonophysics, 492, 1-24. https://doi.org/10.1016/j.tecto.2010.05.021

[22] Guiraud, R. and Bosworth, W. (1999) Phanerozoic Geodynamic Evolution of Northeastern Africa and the Northwestern Arabian Platform. Tectonophysics, 315, 73-108. https://doi.org/10.1016/S0040-1951(99)00293-0

[23] Haddoum, H., Guiraud, R. and Moussine-Pouchkine, A. (2001) Hercynian Compressional Deformations of the Ahnet-Mouydir Basin, Algerian Saharan Platform: far-Field Stress Effects of the Late Palaeozoic orogeny. Terra Nova, 13, 220-226. https://doi.org/10.1046/j.1365-3121.2001.00344.x

[24] Moulin, M., Aslanian, D. and Unternehr, P. (2010) A New Starting Point for the South and Equatorial Atlantic Ocean. Earth Science Reviews, 98, 1-37. https://doi.org/10.1016/j.earscirev.2009.08.001

[25] Wilson, M. and Guiraud, R. (1992) Magmatism and Rifting in Western and Central Africa, from Late Jurassic to Recent Times. Tectonophysics, 213, 203-225. https://doi.org/10.1016/0040-1951(92)90259-9

[26] Burke, K.C. and Dewey, J.F. (1972) Orogeny in Africa. In: Dessauvagie, T.F.J. and Whiteman, A.J., Eds., African Geology, University Press, Ibadan, 583-608.

[27] Boudjema, A. (1987) Evolution structural du basin pétrolier "triasique" du Sahara nord occidental (Algérie). Thèse Doctorat Etat, Université de Paris XI-Orsay, France, $290 \mathrm{p}$.

[28] Guiraud, R. and Maurin, C.J. (1992) Early Cretaceous Rifts of Western and Central Africa: An Overview. Tectonophysics, 213, 153-168. https://doi.org/10.1016/0040-1951(92)90256-6

[29] Smith, B., Derder, M.E.M., Henry, B., Bayou, B., Yelles, A.K., Djellit, H., Amenna, M., Garces, M., Beamud, E., Callot, J.P., Eschard, R., Chambers, A., Aifa, T., Ait Ouali, R. and Gandriche, H. (2006) Relative Importance of the Hercynian and Post-Jurassic Tectonic Phases in the Saharan Platform: A Palaeomagnetic Study of Jurassic Sills in the Reggane Basin (Algeria). Geophysical Journal International, 167, 380-396. https://doi.org/10.1111/j.1365-246X.2006.03105.X

[30] Miller, K.G., Kominz, M.A., Browning, J.V., Wright, J.D., Mountain, G.S., Katz, M.E., Sugarman, P.J., Cramer, B.S., Christie-Blick, N. and Pekar, S.F. (2005) The Phanerozoic Record of Global Sea-Level Change. Science, 310, 1293-1298. https://doi.org/10.1126/science.1116412 
[31] Fabre, J. (2005) Géologie du Sahara Occidental et Central. Tervuren African Geoscience Collection, Vol. 108, Musée Royal de l'Afrique Central, 572 p.

[32] Guiraud, R., Bosworth, W., Thierry, J. and Delplanque, A. (2005) Phanerozoic Geological Evolution of Northern and Central Africa: An Overview. Journal of African Earth Sciences, 43, 83-143. https://doi.org/10.1016/j.jafrearsci.2005.07.017

[33] Leprêtre, R. (2015) Evolution phanérozoïque du Craton Ouest Africain et de ses bordures Nord et Ouest. Sciences de la Terre, Université Paris Sud-Paris XI, Français.

[34] Bellion, Y. (1989) Histoire géodynamique post-paléozoïque de l'Afrique de l'Ouest d'après l'étude de quelques bassins sédimentaires (Sénégal, Taoudeni, Iullemmeden, Tchad). Published PhD Thesis, Université d'Avignon et des pays de Vaucluse, Centre international pour la formation et les échanges géologiques, Paris.

[35] Fabre, J., Arnaud-Vanneau, A., Belhadj, Z. and Monod, T. (1996) Evolution des terrains mésocénozoïques d'une marge à l'autre du craton ouest africain, entre le Tanezrouft (Algérie) et l'Adrar de Mauritanie. In: Bitam, L. and Fabre, J., Eds., Géodynamique du Craton Ouest Africain Central et Oriental: Héritage et Évolution Post-Panafricains, Boumerdès, Vol. 8, Service géologique de l’Algérie, Mémoire du Service Géologique de l'Algérie, Boumerdès, 187-229.

[36] Villeneuve, M. (2008) Review of the Orogenic Belts on the Western Side of the West African Craton: The Bassarides, Rokelides and Mauritanides. In: Ennih, N. and Liégeois, J.P., Eds., The Boundaries of the West African Craton, Geological Society Special Publications, London, 169-201. https://doi.org/10.1144/SP297.8

[37] Villeneuve, M. (2005) Paleozoic Basins of West Africa and the Mauritanides Fold Belt. Journal of African Earth Sciences, 43, 166-195. https://doi.org/10.1016/j.jafrearsci.2005.07.012

[38] Musson, R.M.W. (2013) The Seismicity of Ghana. Bulletin of Earthquake Engineering, 12, 157-169. https://doi.org/10.1007/s10518-013-9555-Z

[39] Grünthal, G., Wahlström, R. and Stromeyer, D. (2009) The Unified Catalogue of Earthquakes in Central, Northern, and Northwestern Europe (CENEC)-Updated and Expanded to the Last Millennium. Journal of Seismology, 13, 517-541. https://doi.org/10.1007/s10950-008-9144-9

[40] Cornell, C.A. (1968) Engineering Seismic Risk Analysis. Bulletin of the Seismological Society of America, 58, 1583-1606.

[41] Gutenberg, B. and Richter, C.F. (1944) Frequency of Earthquakes in California. Bulletin of the Seismological Society of America, 34, 185-188.

[42] Bender, B. and Perkins, D.M. (1987) Seisrisk III: A Computer Programme for Seismic Hazard Estimation. United States Geological Survey Bulletin, 1772, 48 p.

[43] Aki, K. (1965) Maximum Likelihood Estimate of $b$ in the Formula $\log _{10} N=a-$ bm and Its Confidence Limits. Bulletin of Earthquake Research, 43, 237-239.

[44] McGuire, R.K. (1976) FORTRAN Computer Program for Seismic Risk Analysis. United States Geological Survey Open-File Report No. 76-67, U.S. Geological Survey, Washington DC. https://doi.org/10.3133/ofr7667

[45] McGuire, R.K. (1978) FRISK: Computer Program for Seismic Risk Analysis Using Faults as Earthquake Sources. United States Geological Survey Open-File Report No. 78-1007, U.S. Geological Survey, Washington DC. https://doi.org/10.3133/ofr781007

[46] Talwani, P. (1989) Characteristic Features of Intraplate Earthquakes and the Models Proposed to Explain Them. In: Editor, Earthquakes at North-Atlantic Passive Margins. Neotectonics and Postglacial Rebound, NATO ASI Series (Series C: Mathe- 
matical and Physical Sciences), Vol. 266, Springer, Dordrecht, 563-579. https://doi.org/10.1007/978-94-009-2311-9_33

[47] Mooney, W.D., Ritsema, J. and Hwang, Y.K. (2012) Crustal Seismicity and the Earthquake Catalog Maximum Moment Magnitude (Mcmax) in Stable Continental Regions (SCRs): Correlation with the Seismic Velocity of the Lithosphere. Earth and Planetary Science Letters, 357-358, 78-83. https://doi.org/10.1016/j.epsl.2012.08.032

[48] Hong, T.K., Lee, J., Park, S. and Kim, W. (2018) Time-Advanced Occurrence of Moderate-Size Earthquakes in a Stable Intraplate Region after a Megathrust Earthquake and Their Seismic Properties. Scientific Report, 8, Article No. 13331. https://doi.org/10.1038/s41598-018-31600-5

[49] DeGroot, M.H. (1970) Optimal Statistical Decisions. McGraw-Hill, New York, New York

[50] Abramowitz, M. and Stegun, I.A. (1970) Handbook of Mathematical Functions. 9th Edition, Dover, New York.

[51] Campbell, K.W. (1982) Bayesian Analysis of Extreme Earthquake Occurrences, Part I: Probabilistic Hazard Model. Bulletin of the Seismological Society of America, 72, 1689-1705.

[52] Edwards, A.W.F. (1972) Likelihood. Cambridge University Press, New York, 235 p.

[53] Kijko, A. (2004) Estimation of the Maximum Earthquake Magnitude, $m_{\max }$. Pure and Applied Geophysics, 161, 1655-1681. https://doi.org/10.1007/s00024-004-2531-4

[54] Tinti, S. and Mulargia, F. (1985) Effects of Magnitude Uncertainties in the Gutenberg-Richter Frequency-Magnitude Law. Bulletin of the Seismological Society of America, 75, 1681-1697.

[55] Wiemer, S. and Wyss, M. (2000) Minimum Magnitude of Completeness in Earthquake Catalogs: Examples from Alaska, the Western United States, and Japan. Bulletin of the Seismological Society of America, 90, 859-869. https://doi.org/10.1785/0119990114

[56] Kijko, A. and Graham, G. (1999) "Parametric-Historic" Procedure for Probabilistic Seismic Hazard Analysis. Part II: Assessment of Seismic Hazard at Specified Site. Pure and Applied Geophysics, 154, 1-22. https://doi.org/10.1007/s000240050218

[57] Evernden, J. (1970) Study of Regional Seismicity and Associated Problems. Bulletin of the Seismological Society of America, 60, 393-446.

[58] Kagan, Y. (1999) Universality of the Seismic Moment-Frequency Relation. Pure and Applied Geophysics, 155, 537-573. https://doi.org/10.1007/s000240050277

[59] Lay, T. and Wallace, T.C. (1995) Modern Global Seismology. Academic Press, Cambridge, $393 \mathrm{p}$.

[60] Hubert, H. (1915) Les séismes en Afrique Occidentale Française. La Géographie, T30, 359-364.

[61] Bacon, M. and Quaah, A.O. (1981) Earthquake Activity in Southeastern Ghana (1977-1980). Bulletin of the Seismological Society of America, 71, 771-785.

[62] Briden, J.C., Whitcombe, D.N., Stuart, G.W., Fairhead, J.D., Dorbath, C. and Dorbath, L. (1981) Depth of Geological Contrast across the West African Craton Margin. Nature, 292, 123-128. https://doi.org/10.1038/292123a0

[63] Amponsah, P.E. (2002) Seismic Activity in Relation to Fault Systems in Southern Ghana. Journal of African Earth Sciences, 35, 227-234. https://doi.org/10.1016/S0899-5362(02)00100-8

[64] Akoto, M.A. and Anum, S.A. (1992) Monitoring Recent Microseismic Activity in 
Ghana. Tectonophysics, 209, 43-46. https://doi.org/10.1016/0040-1951(92)90007-S

[65] Agrawal, P.N. (1991) Engineering Seismology. IBH Publishing Co. Pvt. Ltd., New Delhi, Oxford.

[66] Scholz, C. (1968) The Frequency-Magnitude Relation of Microfracturing in Rock and Its Relation to Earthquakes. Bulletin of the Seismological Society of America, 58, 339-415.

[67] Shaik, M.A. and Srivastava, S. (2003) Statistical Parameters of Bhuj Earthquake Sequence of January 26th, 2001. Journal of Earth System Science, 112, 397-400. https://doi.org/10.1007/BF02709266

[68] Freeth, J.S. (1978) Tectonic Activity in West Africa and the Gulf of Guinea since Jurassic Times-An Explanation Based on Membrane Tectonics. Earth and Planetary Science Letters, 38, 298-300. https://doi.org/10.1016/0012-821X(78)90103-6

[69] Talwani, P. (2014) A Unified Model for Intraplate Earthquakes. In: Talwani, P., Ed., Intraplate Earthquakes, Cambridge University Press, Cambridge, 275-302. https://doi.org/10.1017/CBO9781139628921.012

[70] Hartnady, C.J.H. and Benouar, D. (2007) African Catalogue of Earthquakes (ACE) Project: Towards Earthquake Risk Reduction in Active Plate-Boundary Zones. $A b$ stract, AfricaArray Workshop, Johannesburg, South Africa, 17-18 July 2007.

[71] Meghraoui, M., Amponsah, P., Bernard, P. and Ateba, B. (2019) Active Transform Faults in the Gulf of Guinea: Insights from Geophysical Data and Implications for the Seismic Hazard Assessment. Canadian Journal of Earth Sciences, 56, 1398-1408. https://doi.org/10.1139/cjes-2018-0321

[72] Ahulu, S.T., Danuor, S.K. and Asiedu, D.K. (2017) Probabilistic Seismic Hazard Assessment of Southern Part of Ghana. Journal of Seismology, 22, 539-557. https://doi.org/10.1007/s10950-017-9721-x

[73] Gupta, I.D. (2002) The State of the Art in Seismic Hazard Analysis. ISET Journal of Earthquake Technology, 39, 311-346.

[74] Kijko, A. (2011) Introduction to Probabilistic Seismic Hazard Analysis. In: Gupta, H., Ed., Encyclopedia of Solid Earth Geophysics, Springer, Dordrecht, 27 p. https://doi.org/10.1007/978-90-481-8702-7_10 